\title{
O005: Results of the french national audit on standard precautions
}

\author{
M Giard ${ }^{1,2^{*}}$, E Laprugne-Garcia ${ }^{1}$, E Caillat-Vallet ${ }^{1}$, I Russell ${ }^{1}$, D Verjat-Trannoy ${ }^{3}$, M-A Ertzscheid ${ }^{4}$, N Vernier $^{5}$, \\ C Laland $^{6}$, A Savey $^{1,2}$, GREPHH $^{1}$
}

From 2nd International Conference on Prevention and Infection Control (ICPIC 2013)

Geneva, Switzerland. 25-28 June 2013

\section{Introduction}

Standard precautions (SP) aim to protect healthcare workers $(\mathrm{HCW})$ and patients from infectious diseases arising from bloodborne pathogens and reduce the risk of cross transmission of micro-organisms. They must be applied in all circumstances, regardless of the infectious status of the patient.

\section{Objectives}

The objectives were to assess: 1 ) institutional policies for SP promotion; 2) available resources for SP implementation; and 3) education of $\mathrm{HCW}$ and their compliance with SP.

\section{Methods}

The study was a mixed audit of procedures, resources and attitudes. It was conducted between February $1^{\text {st }}$ and December $31^{\text {st }} 2011$, supported by the Ministry of Health. Inclusion criteria were voluntary public and private hospitals in France, medical, surgical and medicotechnical wards therein and $\mathrm{HCW}$ working with patients in these wards. Self-assessment questionnaires were administered at three levels: institutional, ward and $\mathrm{HCW}$. At institutional and ward levels, results were given as a percentage of objectives attained; at professional level, percentages of responses reported as "never", "sometimes", "often" or "always" were calculated for each question.

\section{Results}

A total of 1,599 hospitals participated, including 14,968 wards and 203,840 $\mathrm{HCW}$. At institutional level, the overall score was $88 \%$, covering: SP promotion (91\%), procedures (99\%) and SP evaluation (63\%). At ward level, the overall score was $94 \%$, covering: procedures (95\%) and resources (93\%). Among the 165,722 (81.3\%) $\mathrm{HCW}$ who reported having participated in a training session on SP, $69.6 \%$ had had it in the last five years. A total of $88.1 \%$ of HCW knew where to find the appropriate written procedure in the event of a blood exposure. HCW reported the best compliance for glove changing between two patients (94.5\% "always"). The less respected criteria were glove use for intramuscular or subcutaneous injection and eye protection use in the event of blood exposure risk (34.5\% and 24.4\% "always", respectively).

\section{Conclusion}

No study on SP exists in literature which includes such a large participation as this one. It will form a refence basis leading to actions for improvement at local and national level.

\section{Disclosure of interest}

None declared.

\section{Author details}

${ }^{1}$ CClin Sud-Est, Lyon, France. ${ }^{2}$ UMR5558, LBBE, Lyon 1 University, Villeurbanne, France. ${ }^{3}$ CClin Paris-Nord, Paris, France. ${ }^{4}$ CClin Ouest, Rennes, France. ${ }^{5} \mathrm{CClin}$ Est, Nancy, France. ${ }^{6} \mathrm{CClin}$ Sud-Ouest, Poitiers, France.

Published: 20 June 2013

doi:10.1186/2047-2994-2-S1-05

Cite this article as: Giard et al:: 0005: Results of the french national audit on standard precautions. Antimicrobial Resistance and Infection Control 2013 2(Suppl 1):O5.

${ }^{1}$ CClin Sud-Est, Lyon, France

Full list of author information is available at the end of the article

C 2013 Giard et al; licensee BioMed Central Ltd. This is an Open Access article distributed under the terms of the Creative Commons 